\title{
On intergenerational (im)mobility in Latin America
}

\author{
Christian Daude $^{1}$ - Virginia Robano ${ }^{1}$
}

Received: 8 November 2014/ Accepted: 3 October 2015/Published online: 28 October 2015

(C) The Author(s) 2015. This article is published with open access at Springerlink.com

\begin{abstract}
This paper studies intergenerational mobility in Latin America and shows that, in addition to the well-documented fact that the Latin American income distribution is highly unequal, profound differences in opportunities persist from one generation to the next. Comparing final educational achievements for 18 Latin American countries, this paper finds that measures of the persistence in educational achievements across generations, such as beta- and partial correlation coefficients, are high. This persistence is correlated with high returns to education, relatively low progressivity in public investments in education, and inequality of opportunity. An index of inequality of opportunity (including dimensions beyond an individual's control such as race, gender and parental income background) is estimated at around $40 \%$, which is high by international standards. The paper also explores country differences in intergenerational mobility. While in Costa Rica, circumstances explain below $15 \%$ of the observed variance in education, in Chile, they amount to almost half the explained variance. The findings imply that there is room for targeted redistributive policies that improve intergenerational mobility.
\end{abstract}

Keywords Intergenerational mobility - Education - Latin America - Inequality of opportunity · Circumstances

JEL Classification I20 $\cdot$ J62

Christian Daude

christian.daude@oecd.org

1 Organisation for Economic Co-operation and Development, Paris, France 


\section{Introduction}

The present paper analyses the extent of intergenerational transmission of educational achievements in 18 Latin American economies. While there is a large literature on the intergenerational transmission of income and status for developed economies, the evidence on the extent of intergenerational mobility for emerging countries is more restricted (due to data limitations). ${ }^{1}$ In particular, one of the main problems for the analysis of intergenerational mobility for the Latin American region is the unavailability of panel data (selected countries, e.g. Chile and Mexico, have recently started to follow individuals over time) that would enable connecting the income or wealth for parents with the income of their offspring. ${ }^{2}$

However, using representative population samples at the country level for a large number of Latin American countries, this paper can link the educational attainment of parents with that of their children, measuring intergenerational persistence of educational attainment. Moreover, we deepen the analysis by considering different cohorts, as well as the influence of circumstances (e.g. race, gender, parental income background). As education is an important driver of labour market income and measurement errors of parental educational outcomes are much smaller than income-related variables, this approach, which has also been followed in the literature for developing countries, can be implemented for a larger number of countries.

This paper uses three measures of intergenerational educational mobility: the beta-coefficient, the partial correlation coefficient, and the overall effect of circumstances beyond an individual's control (i.e. the index of inequality of opportunity). All measures coincide in pointing out the relatively low degree of intergenerational mobility in Latin America and the importance of parental background in determining educational success.

Within Latin America, there are important differences: while the persistence of educational attainment is relatively low in Costa Rica, Uruguay, Guatemala and Argentina (the beta-coefficient of educational attainment is below $50 \%$ ), in Dominican Republic, Venezuela and El Salvador it is above $70 \%$. The case of Chile is remarkable, as the beta-coefficient shows that the intergenerational persistence in educational achievement is $57 \%$-lower than the average value of $60 \%$-but the partial correlation coefficient is $67 \%$ and the overall index of inequality of opportunity is $48 \%$, the highest value among the sample.

The remainder of the paper is structured as follows. Section "Literature review" places this paper's contributions in context by presenting a brief literature review; Sect. "Methodology and data" describes the conceptual framework to analyse the

\footnotetext{
${ }^{1}$ Black and Devereux (2010) present a recent survey of the evidence and methodological problems of the research available for developed economies, especially the United States. See also Solon (2002) for an earlier survey of the evidence on earning mobility across generations.

2 Azevedo and Bouillon (2010) review the evidence on intergenerational social mobility by summarising a set of papers for Latin America, and find that intergenerational social mobility is lower than the levels observed in the United States or the United Kingdom. The authors also note the unavailability of panel data for the region. Cuesta et al. (2011) use pseudo panels to overcome this problem for a sample of 14 Latin American countries.
} 
intergenerational transmission of educational attainments and presents the data used in the empirical assessment. Section "Empirical results" presents the main results for Latin America and Sect. "Conclusions and some policy implications" discusses potential implications.

\section{Literature review}

Income inequality in Latin America is extremely high compared to other emerging economies as well as high-income countries (e.g. see Hertz et al. 2007 ${ }^{3}$; OECD, 2008; Azevedo and Bouillon 2010; Ferreira and Gignoux 2011, 2013; Brunori et al. 2013; Torche 2014). In principle, this type of static income inequality across individuals (at a certain point in time) does not have to be bad per se, as the dispersion in earnings could act as a strong incentive for parents to invest in their children's education. However, for poor households to be able to grasp these opportunities, they should have access to well-functioning credit markets, as the presence of credit constraints reinforces the intergenerational transmission of income (Aiyagari et al. 2003). ${ }^{4}$

In principle, educational attainment is a key determinant of wage earnings. Therefore, differences in acquired education are important to understand static income inequality.

Hertz et al. (2007) estimate 50-year trends in intergenerational persistence of educational attainment for 42 countries, finding the largest intergenerational correlations in the seven Latin American countries included in their analysis. The authors find that while the beta-coefficient decreased over the last 50 years (suggesting an increase in intergenerational mobility), no trend is observed for the partial correlation coefficient. The authors suggest that while both are linear measures of statistical association and not the true causal effect, the beta-coefficient might overestimate the true structural parameter of intergenerational mobility due to the omission of other explanatory variables.

Building on the terminology proposed by Roemer (1998), which distinguishes between "efforts" (factors that individuals can control) and "circumstances" (factors beyond one's control, such as race, birthplace, or family background) in determining "advantages" (outcomes as a result of the combination of circumstances and effort), Ferreira and Gignoux (2011) propose a scalar measure of inequality of opportunity. They conduct a comparative analysis of six Latin American countries and find that in three of them, inequality of opportunity is linked to racial origin (indigenous or Afro-descendants). ${ }^{5}$ In a later study, Brunori et al. (2013) analyse inequality of opportunity in a comparative form for 41 countries, of

\footnotetext{
${ }^{3}$ Hertz et al. (2007) study the intergenerational transmission of educational outcomes in 50 developed and developing countries using household surveys. They present results for seven countries from Latin America: Brazil, Chile, Colombia, Ecuador, Panama, Peru, and Nicaragua.

4 In Latin America, as documented by Tejerina and Westley (2007) using household surveys, the poor have reduced access to credit and saving instruments.

5 Data for this paper come from nationally representative household surveys dated 1996 for Brazil, 2003 for Colombia, 2006 for Ecuador, 2000 for Guatemala, 2003 for Panama and 2001 for Peru.
} 
which six are in Latin America. ${ }^{6}$ The authors find that inequality of opportunity is positively correlated with income inequality, and negatively related to intergenerational income and educational mobility. Moreover, they find the highest levels of inequality of opportunity for these six Latin American countries among the whole sample considered. ${ }^{7}$

Corak (2013) also links the presence of inequality with lack of opportunities and of mobility. He argues that the presence of inequality shapes opportunities and in turn, lack of opportunity lowers mobility. ${ }^{8}$ By describing the case of the United States, Corak (2013) argues that the "American Dream" (i.e. prospects for upward mobility) makes low income earners not strong advocates of redistributive policies, because of the belief that either they or their descendants can climb the income ladder. ${ }^{9}$ Corak (2013) cites Solon (2004) arguing that the Great Gatsby Curve (the relationship between more income inequality and less intergenerational mobility) can be due to high returns to education. ${ }^{10}$ Parents with high education would have both the capacity and the incentive to invest in their children's education.

Recently, Torche (2014) discusses the literature on equality of opportunity in a set of studies for Latin America. The review finds that parental education is the most influential circumstance for an individual, concluding that inequality of opportunity is higher in Latin America than in industrial countries. Torche argues that the high (albeit decreasing) returns to education in Latin America can foster mobility, but they might also create a situation of "inherited meritocracy", because of the barriers that the lower segments of the income distribution face in accessing education (quantity and quality). Relatedly, Azevedo and Bouillon (2010) associate the high levels of immobility in Latin America with social exclusion, low access to higher education and labour market discrimination. ${ }^{11}$

If societies do not bring equal opportunities based on merit and ability, independent of race, gender or social origin, then today's social and economic status may be transmitted from parents to their offspring. The focus of this paper is precisely the analysis of mobility in terms of educational attainment for parents and children. In particular, a contribution of the paper is enriching the analysis by considering several dimensions: race, gender and parental income, and analysing the robustness of the findings across different measures of intergenerational mobility.

\footnotetext{
6 The countries are Brazil, Colombia, Ecuador, Guatemala, Panama and Peru.

7 See Brunori et al. (2013): Fig. 2, page 26.

${ }^{8}$ Citing Roemer (1998) and Corak (2013) argues that circumstances affect opportunity by three channels: social capital, genetic traits, and family values, and that while policies that affect social capital tend to be accepted, less consensus is placed on policies intending to offset genetic advantages, and within-family investments.

9 Corak (2013) concludes that relatively less upward mobility of the least advantaged is one of the reasons why intergenerational mobility in the United States is lower than in other countries. In addition, Corak (2013) concludes that the persistence at the top $1 \%$ of the income distribution also makes intergenerational mobility in the United States lower than in other countries.

${ }^{10}$ See the Appendix for an analytical framework based on the Solon (2004) model.

11 Nopo et al. (2010) present evidence of racial discrimination in Latin America, while Carrillo, Gandelman and Robano (2014) present evidence of gender discrimination in Latin America.
} 
A second contribution of this paper is to present comparable estimates for 18 countries in the region. With the exception of Cuesta et al. (2011), the available studies generally have covered these issues for a maximum of seven countries, often with larger samples that allow studying specific countries in depth. The present paper's broader country coverage complements this literature by emphasising both the common features within the region, as well as the differences across countries. In contrast to Cuesta et al. (2011), who rely on pseudo cohorts to study intergenerational income mobility, we use the directly reported own and parental education level, which allows us to rely on a larger number of observations (in our sample, we have around 14,000 observations compared to around 1000). This also allows us to have relatively precise estimates for individual countries and explore what drives the differences across countries. Furthermore, while income mobility in principle encompasses educational mobility, income is measured with significantly large errors. Focusing on educational attainment, a key determinant of wages, is easier to observe and quantify, enabling to decrease measurement errors.

Using a novel approach, a series of studies have analysed educational mobility in Latin America by linking the performance of children currently in the education system with the educational attainment of parents, using household surveys (see for example, Behrmann et al. 1999, 2001; Andersen, 2001; Conconi et al. 2007; Gandelman and Robano 2014). These papers analyse the influence of parental background (e.g. income, education) on the success or failure of children in school, where the outcome is a child's completed grade and that corresponding to the child's cohort. However, the education spells are incomplete and therefore mobility might not be measured accurately in using this methodology. In this sense, a third contribution of this paper is that we are able to compare final educational attainments of children with that of their parents.

\section{Methodology and data}

This section describes the estimation techniques used in this paper to account for intergenerational educational mobility, as well as a brief description of the dataset used. We compute three measures of intergenerational educational mobility: the beta-coefficient, which quantifies the rate of transmission of educational achievements between one generation and the next, the correlation coefficient, which in addition takes into account the variation in the dispersion of the educational achievements; and the index of inequality of opportunity, which takes into account an additional set of observed variables (circumstances) in explaining the intergenerational transmission of educational attainment between parents and children.

Each measure has benefits and limitations. The beta-coefficient is very intuitive to understand and shows the difference in intergenerational transmission of education that exists in Latin America compared to the rest of the world. However, beta-coefficient estimates are in general very volatile, and do not take into account the variation in the dispersion of educational attainment for parents and children, which the partial correlation coefficient does. The partial correlation coefficient, in turn, does not consider the effect of other omitted variables that could influence 
intergenerational mobility, thus, we compute also an index of inequality of opportunity, which considers the overall effect of circumstances (race, gender, family income) in explaining own education.

\subsection{Beta- and partial correlation coefficient estimation}

The baseline estimation for an individual $i$ in country $j$ is given by:

$$
E_{i j}=\alpha+\beta \mathrm{PE}_{i j}+\varepsilon_{i j},
$$

where $E$ stands for person $i$ 's own educational attainment, PE the parental educational attainment, and $\varepsilon$ is a white noise disturbance. This equation allows us the quantification of the importance of parental education on own educational attainment using two related measures. The first one is the estimated coefficient of parental education (beta-coefficient). The beta-coefficient shows the relationship between each additional year of education of parents and own education. A higher beta-coefficient implies higher persistence and thus lower intergenerational mobility.

Additionally, one can consider the correlation coefficient between $E$ and PE. ${ }^{12}$ The correlation coefficient shows how much of the observed dispersion in own education is explained by parental education. Again, a higher correlation coefficient implies lower intergenerational mobility. The relationship between the two measures is as follows: the beta-coefficient equals the correlation coefficient between own and parental education weighted by the ratio of the standard deviations of own and parental education:

$$
\beta_{j}=\frac{\sigma_{E_{j}}}{\sigma_{\mathrm{PE}_{j}}} \rho_{E_{j}, \mathrm{PE}_{j}}
$$

Therefore, any apparent divergence between the two measures can be due to changes in the ratio of standard deviations.

Moreover, we include a squared term of parental education, to explore the possibility of a non-linear relationship between intergenerational education attainments and also include country fixed-effect, which enables capturing systematic differences across countries in unobservable factors at the country level that might be correlated with parental education (adding the term $\mu_{j}$ ), estimating therefore:

$$
E_{i j}=\alpha+\mu_{j}+\beta \mathrm{PE}_{i j}+\delta\left(\mathrm{PE}_{i j}\right)^{2}+\varepsilon_{i j}
$$

and

$$
E_{i j}=\alpha+\mu_{j}+\beta \mathrm{PE}_{i j}+\varepsilon_{i j},
$$

OLS estimates of the above equations are potentially biased upwards if there is significant transmission of ability and other unobservable characteristics from

\footnotetext{
12 When considering a more general set-up with multiple regressors, these moments are conditional on all other variables, i.e. partial correlations.
} 
parents to their offspring (i.e. the error term follows an autoregressive process). Although the debate regarding the relative importance of innate characteristics versus environmental conditions ("nature versus nurture") is not settled (see Björklund et al. 2007), there is evidence that the inheritance of cognitive skills has only limited importance as a driver of intergenerational mobility (OECD 2008).

\subsection{Index of inequality of opportunity estimation}

There might be additional variables influencing own educational achievement that are correlated with parental education and affecting also the beta-coefficient. Therefore, in the spirit of Ferreira and Gignoux (2011, 2013), we construct a scalar measure of inequality of opportunity that combines the overall effect of circumstances on an individual's educational attainment. We thus augment the baseline estimation and consider:

$$
E_{i j}=\alpha+\mu_{j}+\beta \mathrm{PE}_{i j}+\varphi \text { White }_{i j}+\gamma \text { Female }_{i j}+\kappa \mathrm{PID}_{i j}+\varepsilon_{i j},
$$

where White is a binary variable indicating self-reported racial origin; Female is a binary variable indicating whether individual is female, and PID stands for parent income ten-quantile classification, self-reported by the offspring. Following Ferreira and Gignoux $(2011,2013)$ definitions and calculations, we compute here the overall effect of (our own defined set of) circumstances on the final educational attainment of individuals and construct an index of inequality of opportunity, a scalar that measures the proportion of the whole variance that is explained by the set of predefined circumstances. The index of inequality of opportunity $\left(\theta_{\mathrm{IOp}}\right)$ that we estimate here for each country $\mathrm{j}$ derives from Eq. (5) and is thus:

$$
\hat{\theta}_{I O p}=\frac{\operatorname{Var}\left(\hat{E}_{j}\right)}{\operatorname{Var}\left(E_{j}\right)},
$$

where $\hat{E}$ comes from the parametric estimation of Eq. (5), the reduced-form regression of own educational attainment on circumstances, for the average person within each type of circumstance. ${ }^{13}$

\subsection{Data description}

Data come from Latinobarómetro, a public opinion survey conducted annually in Latin America. For the 2008 survey, over 20,000 interviews were conducted in 18 Latin American countries. The samples are representative of the national population. Roughly 1000-1200 interviews by country are conducted, with an estimated $3 \%$ sampling error. ${ }^{14}$ Despite the smaller sample size of Latinobarómetro

\footnotetext{
13 There are a maximum of 16 years of education, two racial classifications, two gender classifications and ten parental income decile classifications.

14 See more at http://www.latinobarometro.org.
} 
surveys, there are no significant differences between the average years of education in our sample and those resulting from national household surveys. ${ }^{15}$

Table 1 presents summary statistics of our main variables of interest: (own) education and parental education. ${ }^{16}$ In all countries, there is a significant increase in the years of education (and the level attained) from one generation to the other. On average, the years of education increased by 3 years. At median levels, while parents' educational attainment is lower than completed primary education, even at the 25th percentile of children's educational distribution, primary education is completed.

The increase in educational attainment for children has been larger in most countries that started at very low levels of parental education (e.g. 4.1 years in El Salvador), although Nicaragua is an exception with the lowest increase, despite exhibiting low levels of parental educational attainment.

There are also important differences across countries. For example, higher income countries exhibit systematically higher levels of education across all points of the distribution. For example, in Argentina and Chile, $50 \%$ of the population has completed secondary education and the lowest $25 \%$ still have at least completed primary education. In contrast, Guatemala still exhibits large levels of illiteracy and even the upper 25 percentile has on average 6.5 years of education, i.e. just a little bit more than complete primary education.

Finally, in most countries, the data show some intergenerational convergence in the years of education, as the growth in educational attainment is higher at the lower end of the distribution. For example, while in most countries the lower 25 percentile of parents were basically illiterate with zero years of formal education-while in Argentina, Chile, Colombia, Paraguay, Peru, Uruguay and Venezuela they had at least some primary education-many of these countries present increases in education toward complete primary education. Furthermore, in general, the median has also benefitted more than the upper 25 percentiles in terms of increases in educational attainment. ${ }^{17}$ However, these average trends could be consistent with very little as well as high levels of intergenerational mobility. Thus, an analysis of considering the families' trajectories can provide further insight.

\section{Empirical results}

In this section, we present the estimates of the three measures of intergenerational educational mobility outlined above. First, we present the baseline estimations of the correlations between own and parental educational achievement, comparing them to the empirical evidence available for other regions, countries and datasets. Second, we explore potential differences across gender, cohorts and non-linear

\footnotetext{
${ }^{15}$ Using information from CEDLAS SEDLAC database on average years of education in the 18 countries covered by Latinobarómetro, the average difference in years of education for the population over 25 years old is 0.04 , which is not significant at conventional levels of confidence.

16 See Table 7 for summary statistics by country.

17 Of course, part of the story is that for high levels of education, the offspring is naturally constrained to increase its education further.
} 
Table 1 Descriptive sample statistics of years of education by country

\begin{tabular}{|c|c|c|c|c|c|c|c|c|c|c|}
\hline & \multicolumn{5}{|c|}{ Own education (years) } & \multicolumn{5}{|c|}{ Parental education (years) } \\
\hline & Mean & $\begin{array}{l}\text { Std } \\
\text { Dev }\end{array}$ & $\begin{array}{l}\text { 25th } \\
\text { pctl. }\end{array}$ & Median & $\begin{array}{l}\text { 75th } \\
\text { pctl. }\end{array}$ & Mean & $\begin{array}{l}\text { Std } \\
\text { Dev }\end{array}$ & $\begin{array}{l}\text { 25th } \\
\text { pctl. }\end{array}$ & Median & $\begin{array}{l}\text { 75th } \\
\text { pctl. }\end{array}$ \\
\hline Argentina & 10.40 & 3.61 & 7 & 12 & 13 & 7.57 & 4.18 & 6 & 7 & 12 \\
\hline Bolivia & 8.14 & 5.07 & 4 & 8 & 12 & 4.83 & 5.17 & 0 & 3 & 9 \\
\hline Brazil & 7.66 & 4.68 & 4 & 8 & 11 & 4.33 & 4.33 & 0 & 4 & 8 \\
\hline Colombia & 9.08 & 4.82 & 5 & 11 & 13 & 5.12 & 4.56 & 1 & 5 & 7 \\
\hline Costa Rica & 7.84 & 4.39 & 5 & 6 & 11 & 4.77 & 4.10 & 0 & 6 & 6 \\
\hline Chile & 10.64 & 3.92 & 8 & 12 & 12.5 & 8.40 & 4.54 & 5 & 8 & 12 \\
\hline Dom. Rep. & 8.22 & 4.77 & 6 & 8 & 12 & 5.46 & 4.92 & 0 & 5 & 9 \\
\hline Ecuador & 8.05 & 4.75 & 6 & 6 & 12 & 5.44 & 4.65 & 0 & 6 & 6 \\
\hline El Salvador & 6.70 & 5.00 & 2 & 7 & 10 & 2.60 & 4.25 & 0 & 0 & 5 \\
\hline Guatemala & 4.51 & 4.56 & 0 & 4 & 6.5 & 2.49 & 3.96 & 0 & 0 & 5 \\
\hline Honduras & 6.04 & 4.08 & 2.5 & 6.5 & 9 & 2.76 & 3.78 & 0 & 0 & 6 \\
\hline Mexico & 8.61 & 4.82 & 6 & 9 & 12 & 5.03 & 5.05 & 0 & 4 & 9 \\
\hline Nicaragua & 5.53 & 4.72 & 1 & 5 & 9 & 3.61 & 4.56 & 0 & 2 & 6 \\
\hline Panama & 8.05 & 4.78 & 5 & 8 & 12 & 4.45 & 4.98 & 0 & 3 & 7 \\
\hline Paraguay & 8.89 & 4.21 & 6 & 9 & 12 & 6.19 & 4.24 & 3 & 6 & 9 \\
\hline Peru & 9.07 & 4.79 & 6 & 11 & 13 & 6.28 & 5.30 & 1 & 6 & 11 \\
\hline Uruguay & 8.74 & 3.73 & 6 & 9 & 12 & 6.77 & 3.74 & 6 & 6 & 9 \\
\hline Venezuela & 10.62 & 4.04 & 8 & 11 & 15 & 7.36 & 4.73 & 6 & 6 & 11 \\
\hline
\end{tabular}

Parental education refers to the highest level attained by the father or mother

Source: Based on Latinobarómetro 2008 survey

effects. Third, we explore differences across countries in intergenerational mobility. Finally, we explore the potential drivers of these cross-country differences across Latin American countries.

\subsection{Pooled beta- and correlation coefficient estimations}

In Table 2, we present the estimates for Eqs. (1) and (2), the beta and correlation coefficient estimates for the population at least 25 years old in 2008. The first column shows that parental education has a statistically significant impact for all the specifications considered. In terms of the estimated beta-coefficient, an additional year of parental education increases on average the offspring's education by 0.65 years (or 0.61 if country dummies are included), a result consistent with the estimates found by Hertz et al. (2007) for a smaller sample of countries.

The partial correlation coefficient shows that parental education accounts for around $61.2 \%$ of the dispersion in its offspring's educational attainment in our sample. According to Hertz et al. sample of 42 countries, the average correlation coefficient between own and parental education is around 0.4. Figure 1 shows that 
Table 2 Beta and correlation coefficient estimates

\begin{tabular}{lllll}
\hline & Beta-coefficient & Correlation coefficient & $R^{2}$ & Country fixed effects \\
\hline 1. & $0.653(0.006)^{* * *}$ & 0.612 & 0.374 & No \\
2. & $0.605(0.007)^{* * *}$ & 0.566 & 0.403 & Yes \\
\hline
\end{tabular}

Robust standard errors in parentheses

Number of observations in all regressions: 14,196

*** Significant at $1 \%, * *$ significant at $5 \%$, significant at $10 \%$

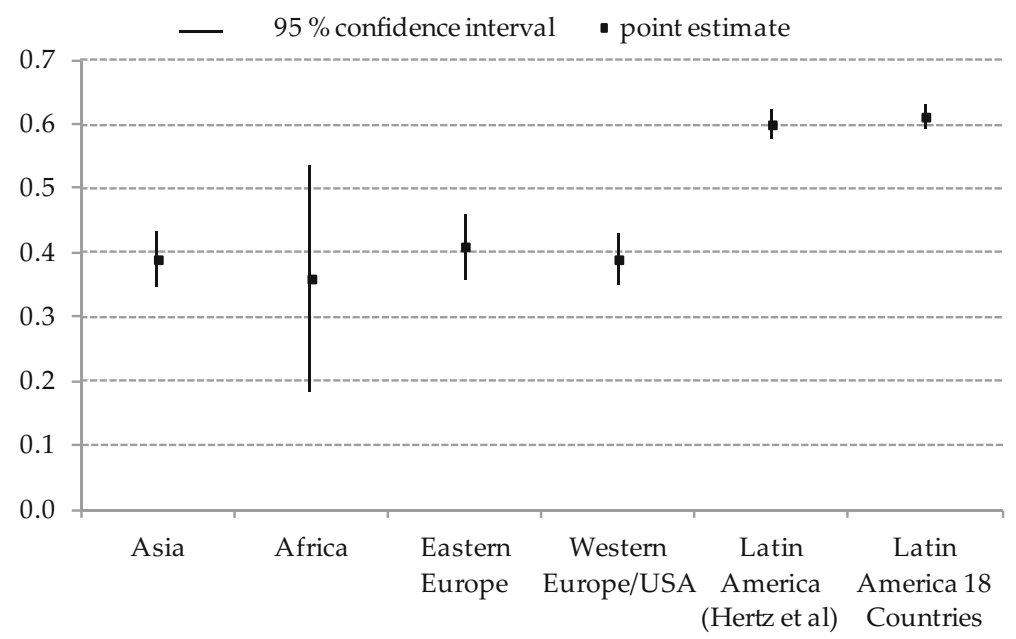

Fig. 1 Regional average correlation coefficients between own and parental education. Asia includes Bangladesh, China (rural), East Timor, Indonesia, Malaysia, Nepal, Pakistan, Philippines, Sri Lanka, and Vietnam; Africa: Egypt, Ethiopia (rural), Ghana, South Africa; Eastern Europe: Czech Republic, Estonia, Hungary, Kyrgyzstan, Poland, Slovakia, Slovenia, Ukraine; Western Europe/USA: Belgium, Denmark, Finland, Ireland, Italy, Netherlands, New Zealand, Northern Ireland, Norway, Sweden, Switzerland, United Kingdom and USA. Source: Hertz et al. (2007) for Asia, Africa, Eastern Europe, Western Europe/ USA and Latin America; own calculations based on Latinobarómetro 2008 survey for 18 Latin American countries

this average is relatively stable across developed and developing regions, with the exception of Latin America. Thus, parental background explains a significantly higher fraction of the variation in educational attainment in Latin America than elsewhere. Figure 1 also shows that our pooled estimate for the 18 Latin American countries in our sample is very close to the average estimate by Hertz et al. (2007) for the seven countries in their sample for the partial correlation coefficient.

Therefore, these first estimates show a consistent picture with the previous literature on intergenerational educational mobility in emerging economies. While the beta-coefficient shows that an additional year of parental schooling adds 0.65 years to the child's educational attainment, a significant number but not particularly high in international terms, the correlation coefficient tells a bleaker 
story for mobility in Latin America. This apparent contradiction can be explained based on Eq. (2), as two countries can present the same beta-coefficient, but the correlation coefficient can be very different if the relative dispersions in parental and/or child education fluctuate.

Regarding the correlation coefficient measure of mobility, adding the squared term does not significantly increase the importance of parental background, as it moves just marginally from 0.612 to 0.620 .

We analyse next whether this persistence of educational attainments has varied across cohorts. We estimate Eq. (4) for four separate cohorts, and present the results in a set of figures, considering separately the variations by gender.

Figure 2 shows the beta-coefficient estimate, suggesting that the persistence of educational attainments decreases across cohorts, implying higher levels of mobility for the younger generations. A quantification of the impact of the intergenerational transmission of educational attainment for individuals in the 25- and 34-year-old cohort is between 23 and $33 \%$ smaller (women and men, respectively) to those over 55 years old in 2008 .

However, the analysis of the correlation coefficient shows that there is no significant change across generations in this measure of educational mobility (see Fig. 3). There are no significant differences by gender.

A plausible explanation for the discrepancy between beta and rho can be due to changes in the standard deviations of own education $\sigma_{\mathrm{E}}$, and parental education, $\sigma_{\mathrm{PE}}$. To assess this possibility, the left-hand panel of Fig. 4 shows the steady increase in average education across cohorts. The right-hand side shows that while the dispersion of own education has remained fairly constant (with some decline for younger generations), the dispersion in parental education is significantly higher for younger cohorts. Thus, the $\beta$-coefficient is lower for the young cohorts due to the fact that the standard deviation of parental education is higher for younger cohorts, as also shown by Daude (2011).

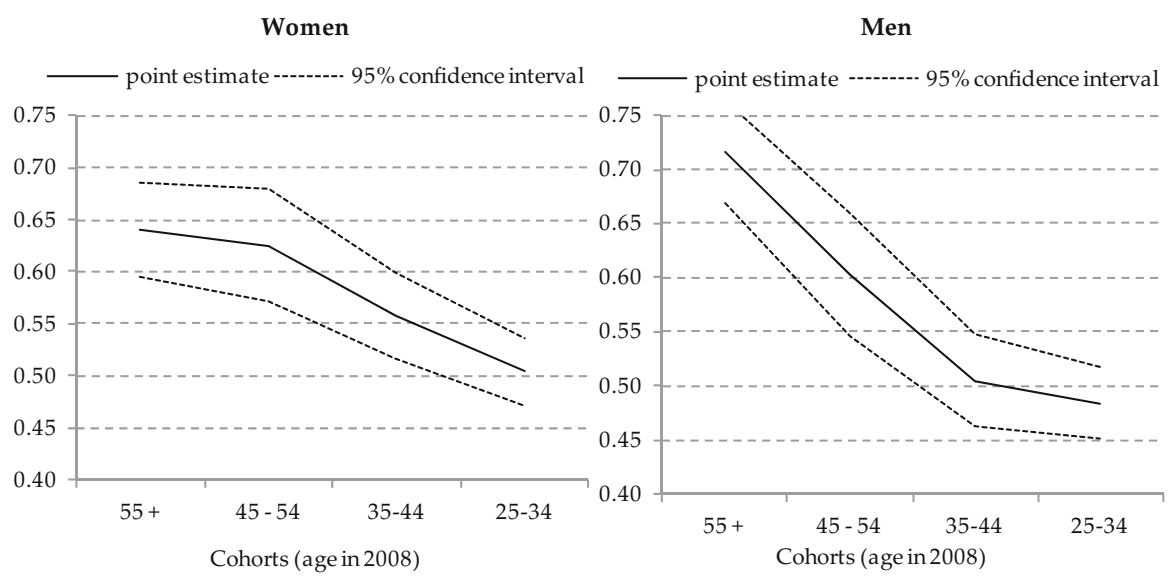

Fig. 2 Beta-coefficient estimation 


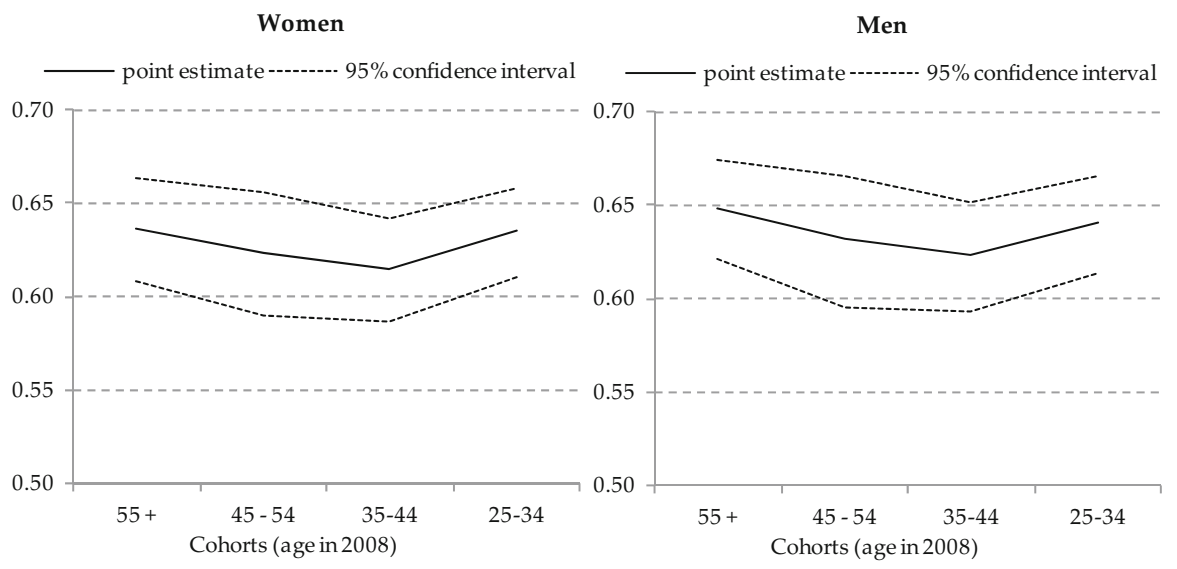

Fig. 3 Correlation coefficient
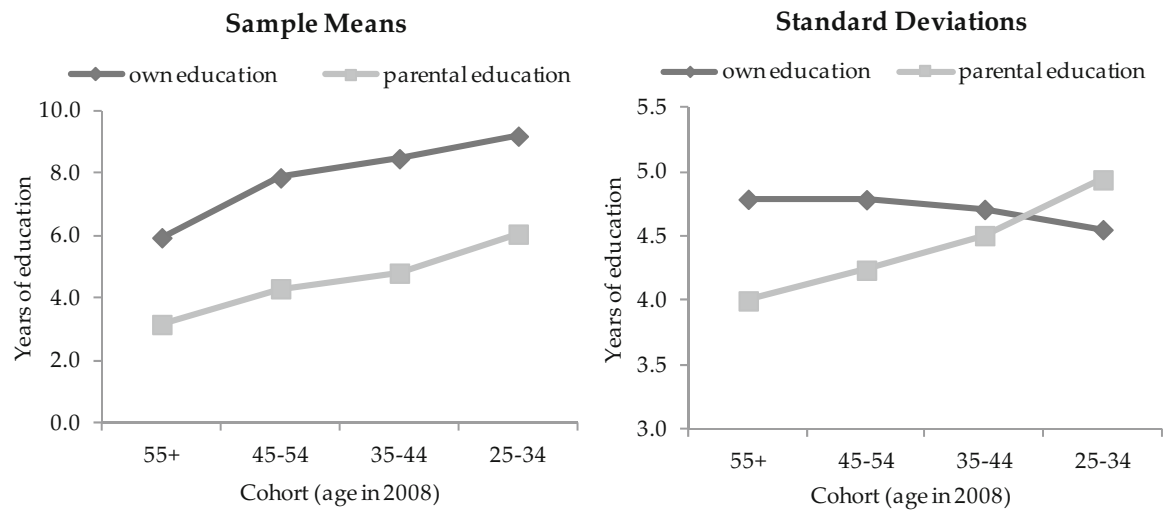

Fig. 4 Sample moments by cohorts

In Table 3, we present the results from estimating Eq. (3), which considers the possibility of a non-linear relationship between own and parental education. The new estimates imply that the tipping point, where an additional year of parental education would start to have a negative effect, is at around 22 years of parental education, which is well beyond the maximum of 16 years observed in our sample. This result could be driven by the fact that upward mobility is more common than downward mobility, such that individuals whose parents had high levels of education are also likely to remain at the higher end of the distribution, while those with very low-level parental background can by definition only move up. In terms of the correlation coefficient, these estimates are very close to the ones reported in Table 2. Therefore, non-linearities do not seem to play a major role.

Overall, the estimates presented so far confirm that for both measures our pooled estimates are in line with the previous literature on intergenerational educational 
Table 3 Augmented OLS estimations

(1)

\begin{tabular}{lll}
\hline Parental education (years) & $0.938(0.019)^{* * * *}$ & $0.852(0.021)^{* * *}$ \\
Parental education squared & $-0.022(0.001)^{* * *}$ & $-0.019(0.001)^{* * *}$ \\
Constant & $4.552(0.056)^{* * *}$ & $5.529(0.129)^{* * *}$ \\
Observations & 14,196 & 14,196 \\
$R^{2}$ & 0.384 & 0.410 \\
Correlation coefficient $^{\mathrm{a}}$ & 0.620 & 0.573 \\
Country dummies & No & Yes \\
\hline
\end{tabular}

Robust standard errors in parentheses

*** Significant at $1 \%, * *$ significant at $5 \%$, significant at $10 \%$

${ }^{a}$ For the regression including country dummies, the correlation coefficient refers to the partial correlation (between residuals of regressing in a first step parent and child education on country dummies)

mobility, despite differences in sampling and years covered. Our estimates also show that the importance of parental education in explaining differences across their children's educational attainment—-measured by the correlation coefficient—is very high compared to other countries and stable across cohorts.

\subsection{Index of inequality of opportunity $\theta$}

In this section, we present the estimates from Eq. (5), augmenting the baseline estimation to include the effect of additional variables beyond an individual's control, such as race (self-reported white versus non-whites), gender, and family income (self-reported parental income status) in the correlation between parental and own educational achievements. ${ }^{18} \mathrm{We}$ include these additional observed variables in the regressions presented in Table 4, both as additional explanatory variables and also their interactions with parental education allowing for a differential effect across groups. The results show an index of inequality of opportunity $\left(\theta_{\mathrm{IOp}}\right)$ for the region of around 0.38 , in line with Ferreira and Gignoux (2013) estimates of 0.35 worldwide and above 0.30 for Argentina, Brazil and Chile). ${ }^{19}$

The results show that overall the baseline estimates from Table 2 are robust to the inclusion of these additional controls. While self-reported white individuals have on average 0.42 more years of education, there is no difference in the educational mobility between white and non-white individuals (columns 1 and 2). The interaction term - which is actually negative — is only marginally significant at $10 \%$ and economically small. Females present lower levels of educational

\footnotetext{
${ }^{18}$ Given that there might be other circumstances beyond an individual's control that are not included in this regression, the measure of $\theta$ shall be considered as a lower bound estimate of inequality of opportunity.

19 The estimates from Ferreira and Gignoux (2011) do not show a clear geographical pattern in the index of Inequality of Opportunity.
} 


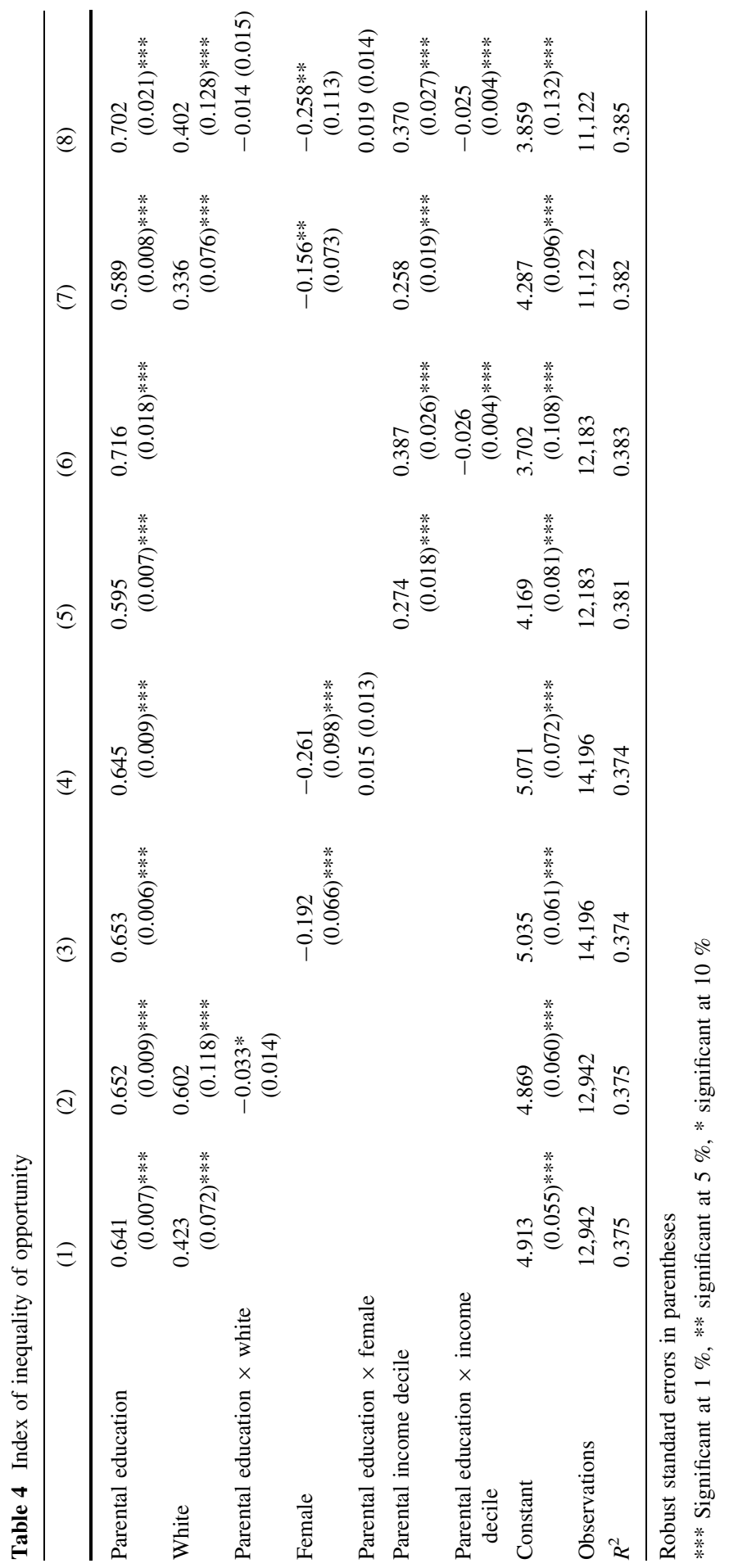


attainment than men (see columns 3 and 4), and again, there is no difference in the interaction term. The 10-decile classification of parental income is associated with higher levels of educational attainment (see columns 5 and 6). The interaction term of parental income and parental education is statistically significant and negative. However, it is relatively small and the mean effect dominates. For example, for all levels below 16 years of parental education, somebody in the highest decile would have a higher predicted level of education based on the estimates of column (6) than somebody in the first decile. ${ }^{20}$ Considering all circumstances together (columns 7 and 8) explains more almost $40 \%$ of the variance of own education. Two final issues are of interest. First, adding more controls does not change dramatically the beta-coefficient (columns 1, 3 and 5), which remains between 0.60 and 0.65 , close the baseline estimate of 0.61 from Table 1 . Second, adding the additional controls does not affect significantly the variance explained by the model. While including only parental education yields a $R^{2}$ of 0.375 (Table 1 ), adding parental income, the gender and white dummies increase the $R^{2}$ just to 0.382 . By contrast, when excluding parental education, the $R^{2}$ is just 0.09 (not shown due to space considerations). Therefore, parental education seems to be a key variable to understand the external circumstances that condition opportunities.

\subsection{Comparisons between countries}

Figure 5 shows estimates for both measures of persistence of educational attainment by country, and their $95 \%$ confidence intervals. There is considerable variation in the region in both measures. For example, while Costa Rica presents a betacoefficient of 0.36 , for Guatemala it is 0.68 , almost twice as large. These differences are economically significant. For example, the elasticities imply that a 4-year difference in parental education would on average imply 1.6 years more of education for the next generation in Costa Rica, while in Guatemala the equivalent figure would be 3.4 years. Given a year of additional education is worth $12 \%$-the average return to education in Latin America ${ }^{21}$ - these extra years could translate into a differential in wage earnings of 19 and $41 \%$, respectively. ${ }^{22}$

In general, countries that show low mobility using the beta-coefficient measure also present low correlation coefficient mobility. ${ }^{23}$ The case of Chile is somewhat atypical, given that it ranks relatively well in terms of the beta-coefficient measure, compared to other countries in the region. However, the correlation coefficient shows that Chile is second only to Guatemala when measuring intergenerational mobility by the correlation coefficient (which quantifies the dispersion in educational achievement within a generation).

In Table 5, we present the estimates of intergenerational mobility by country, adding a set of circumstances in explaining educational attainment. First, column (1)

\footnotetext{
20 This effect is even larger as income and education are positively correlated (0.33 in our sample).

21 Psacharopoulos and Patrinos (2004).

22 Although many of the differences between the point estimates are not statistically significant at standard levels of confidence.

23 The correlation coefficient between the two measures in our sample is 0.75 , significant at $1 \%$.
} 


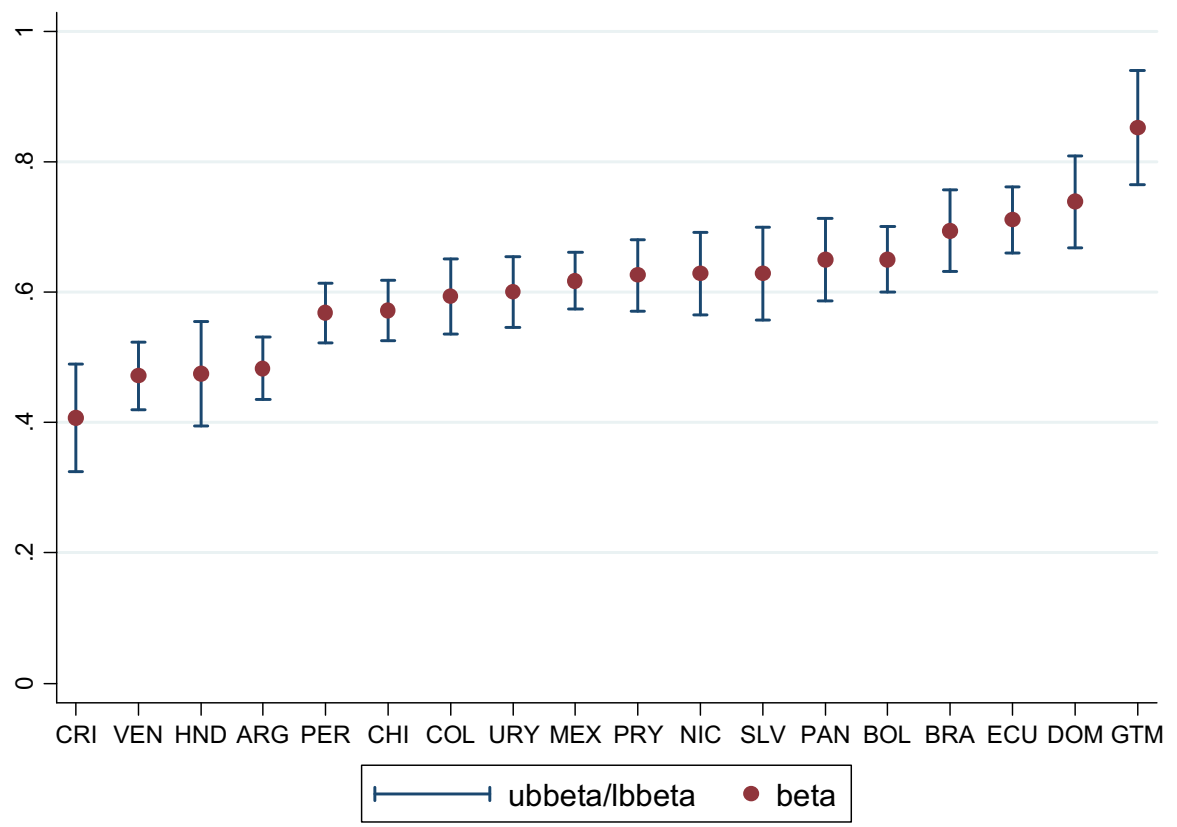

Fig. 5 Beta-coefficient by country

shows that the coefficient indicating intergenerational persistence of educational attainment is always significant, and there is no large variation among countries. Being white (column 2) has a positive significant impact on educational persistence in Argentina, Brazil, Panama and Venezuela, while in Bolivia and Mexico, the impact is significant but negative (thus implying for these two countries that mobility is higher for the non-white). In column 3, the effect of being female on educational attainment is shown: females show lower persistence of intergenerational educational attainment in Bolivia, Chile, El Salvador, Paraguay and Peru. Column 4 shows the coefficient of parental income classification: with the exception of Brazil, parental income is significant in explaining own educational attainment in all countries (Fig. 6).

Furthermore, we compute the index of inequality of opportunity considering the set of circumstances described above (see Fig. 7). The pattern is very similar to the one found above by the beta- and the correlation coefficient: in Costa Rica, circumstances explain the lowest proportion of the variation in own educational attainment, which implies a higher chance of intergenerational mobility. By contrast, in Guatemala, Chile and Ecuador, circumstances beyond an individual's control explain most of the observed variation in educational attainment.

Therefore, this analysis that includes additional circumstances beyond parental education shows that these factors vary across country, but overall parental education is a robust predictor of own education in the region. ${ }^{24}$ Actually, the

\footnotetext{
${ }^{24}$ These estimates should be seen as a lower bound of inequality of opportunity, as other relevant circumstances that are omitted from the analysis are likely to be positively correlated with the explanatory variables, which would be causing an attenuation bias in the estimates.
} 


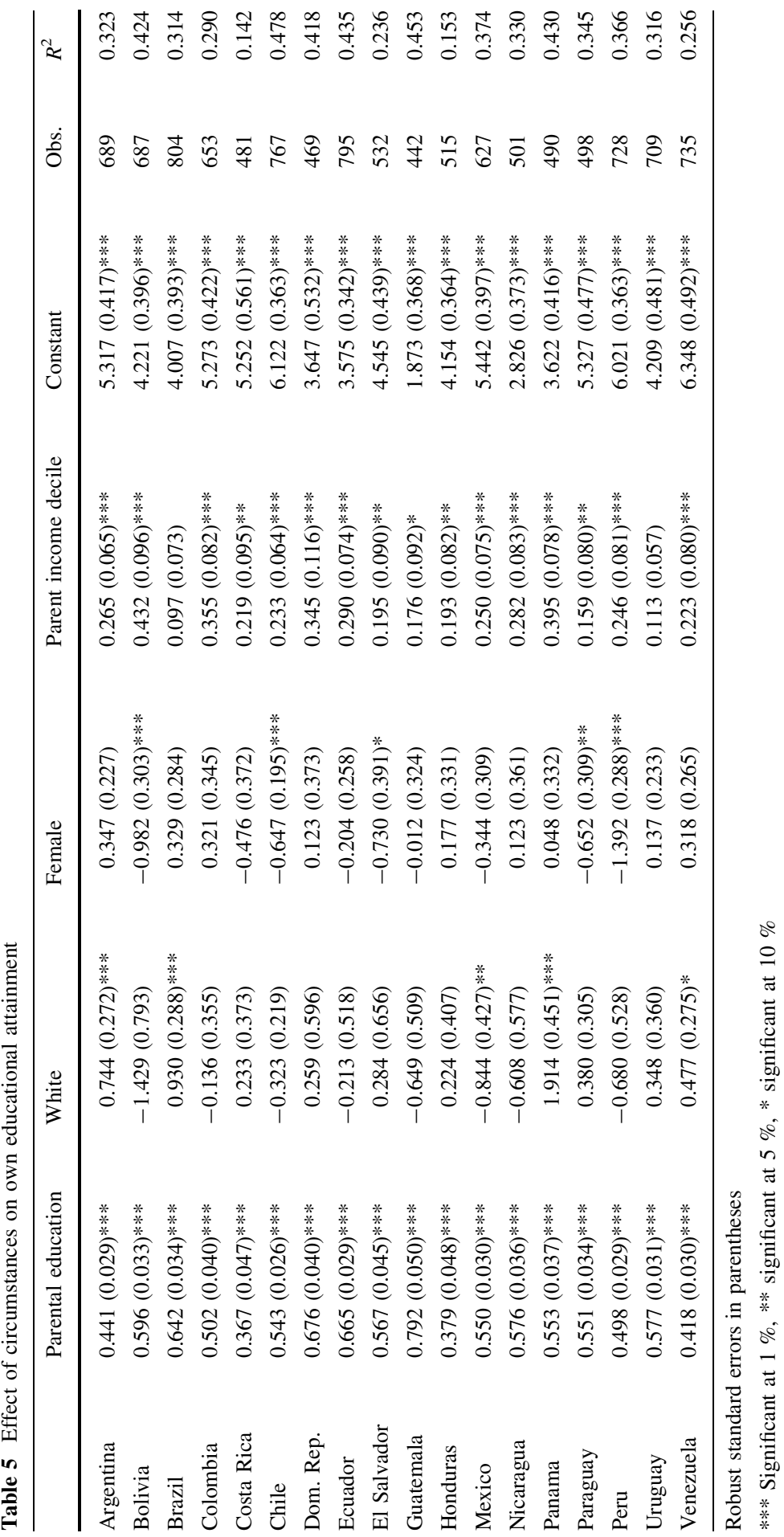




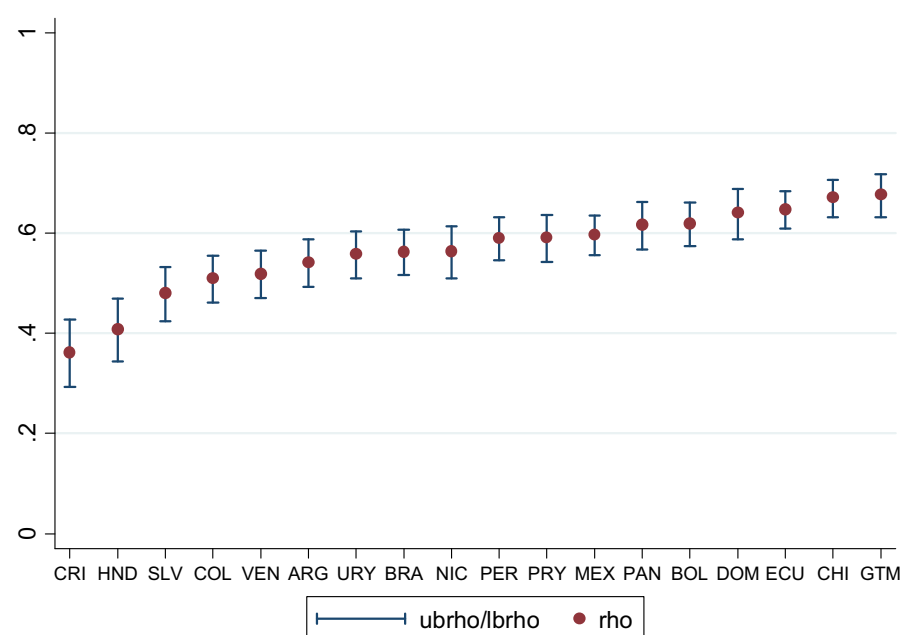

Fig. 6 Correlation coefficient by country

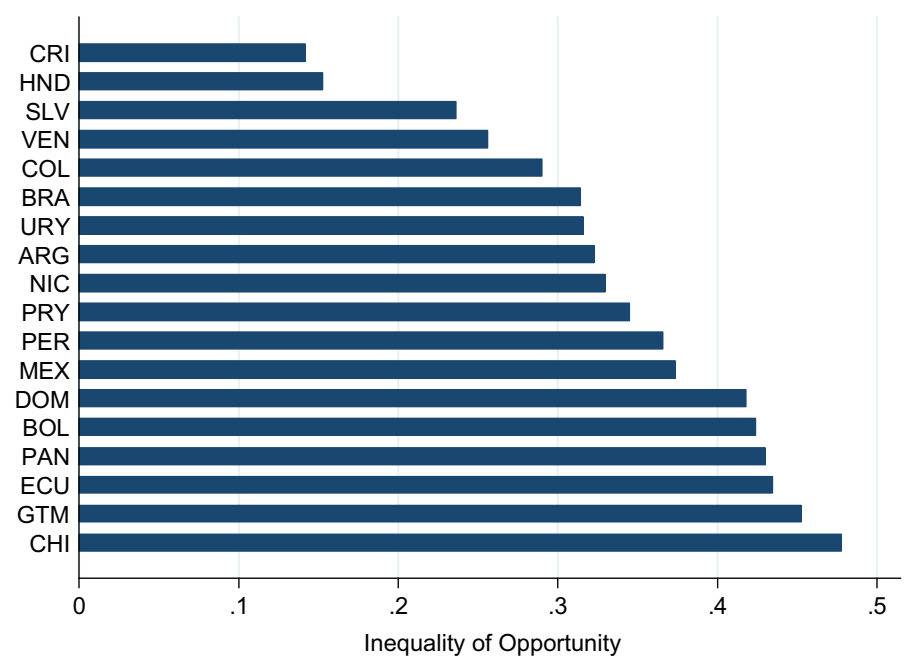

Fig. 7 Index of Inequality of opportunity

correlation between the index of inequality of opportunities and the correlation coefficient between parental and own education is 0.98 in our sample. This does not mean that parental education is a sufficient statistic to understand differences in educational outcomes, but it seems to be an important driver. 


\subsection{Drivers of differences in intergenerational mobility across countries}

This section explores some of the possible determinants of intergenerational mobility. Rather than presenting causal evidence, it shows some cross-country correlations to motivate future research in this area. As Angrist and Pischke (2009) point out, correlation is an important predictor of the existence of causality.

Figure 8 shows the relationship between the beta and partial correlation coefficient and three variables that economic theory considers potential drivers: income inequality, the returns to education and public education expenditure (see the Appendix). To reduce causality problems, we use the earliest available data, which in general are around the mid-1990s.

In terms of income inequality (measured by the Gini index), there is a positive correlation with both measures of intergenerational persistence across countries in the region. The correlation coefficient is 0.44 for the beta-coefficient and 0.37 for the partial correlation coefficient. Therefore, societies in Latin America that are less mobile tend also to exhibit high levels of inequality. According to the analytical framework described in the Appendix, the same factors that affect intergenerational mobility (private returns to education, progressivity of public investment in education, and other transmissible factors such as abilities, race and social networks) also determine the cross-sectional distribution of income in the long run. In the transition period, a decline in income inequality (perhaps due to changes in the skill premium or returns to education) or an increase in the progressivity of public expenditure on education would cause an increase in social mobility.

Figure 8 also shows the correlation of educational mobility and the returns to primary education. While for the beta-coefficient the correlation between intergenerational persistence and higher returns to education is significantly positive, as predicted above, for the correlation coefficient it is much weaker. A plausible explanation is that in countries where the returns to education are high-and poor households face credit constraints - households with higher parental education (and probably income) will take advantage to investing more in education, while poor households cannot afford to do so. The weaker link between the partial correlation coefficient and the returns to primary education might be driven by our small sample size. In fact, when including also OECD countries, Daude (2011) finds a significantly positive correlation between the returns to education and the partial correlation coefficient.

Progressive investment funded by the public sector could equalise opportunities for children of different social and economic background. The empirical evidence shows a negative relationship between both measures of the intergenerational persistence of educational outcomes and public expenditure on education per student relative to GDP per capita, suggesting that public investment in education could foster mobility in the region. A remaining problem to solve is on the quality of education. To be effective, policy actions need to address quality as well as quantity - as findings for OECD countries show that how spending on education is used often matters more than how much is spent. ${ }^{25}$

${ }^{25}$ See OECD (2010). 

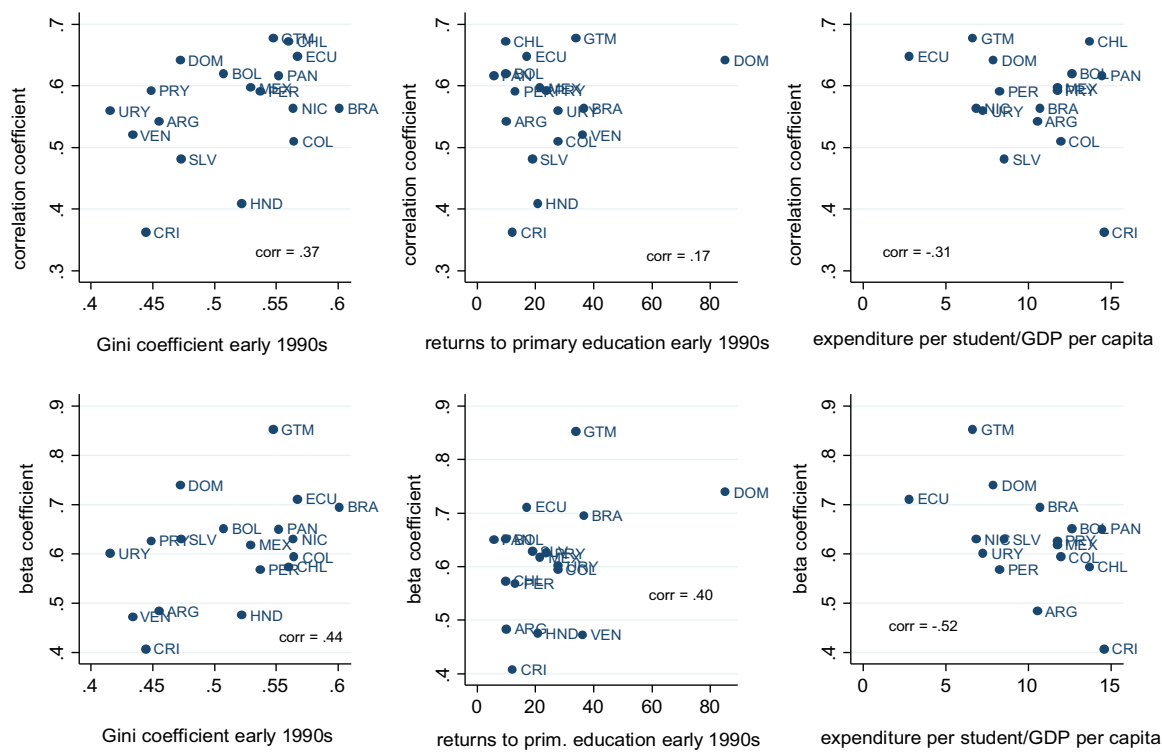

Fig. 8 Income inequality and intergeneration persistence in education. Own calculations based on SEDLAC data and World Bank. Expenditures refer to public expenditure per student in primary education relative to GDP per capita. Returns to education are from Psacharopoulos and Patrinos (2004)

Public expenditure is only part of the picture. Limited access to credit or savings can also be a significant hurdle to investment in education. In Latin America, credit access is likely to be holding children back from pursuing further studies. ${ }^{26}$ The significant correlation between private returns to educational investment and intergenerational persistence in educational attainments could be mitigated by increasing the access to financial markets and specially designed programs that reduce borrowing constraints.

Table 6 looks at the statistical significance of the three variables considered for the beta and partial correlation measures. The results confirm our discussion above. The point estimates for both measures are consistent with what theory would predict-lower mobility is associated with more income inequality and higher returns to education and negatively associated with more public expenditure in education. However, the fit is significantly better for the beta-coefficient, where all variables are significant at $10 \%$ (column 4) and explain around $60 \%$ of the cross country variation. For the correlation coefficient, the variables are only marginally significant, and all together explain around $31 \%$ of the variation across countries.

Based on the regression for the beta-coefficient in Table 6, we can analyse the relative importance of each factor in explaining the intergenerational persistence in education by country. ${ }^{27}$ Figure 9 shows the contribution of each variable in

\footnotetext{
26 Aiyagari et al. (2003), Becker and Tomes (1979, 1986) and Solon (2004).

27 As the estimates for the correlation coefficient are not significant, we present only the analysis for the correlation coefficient.
} 


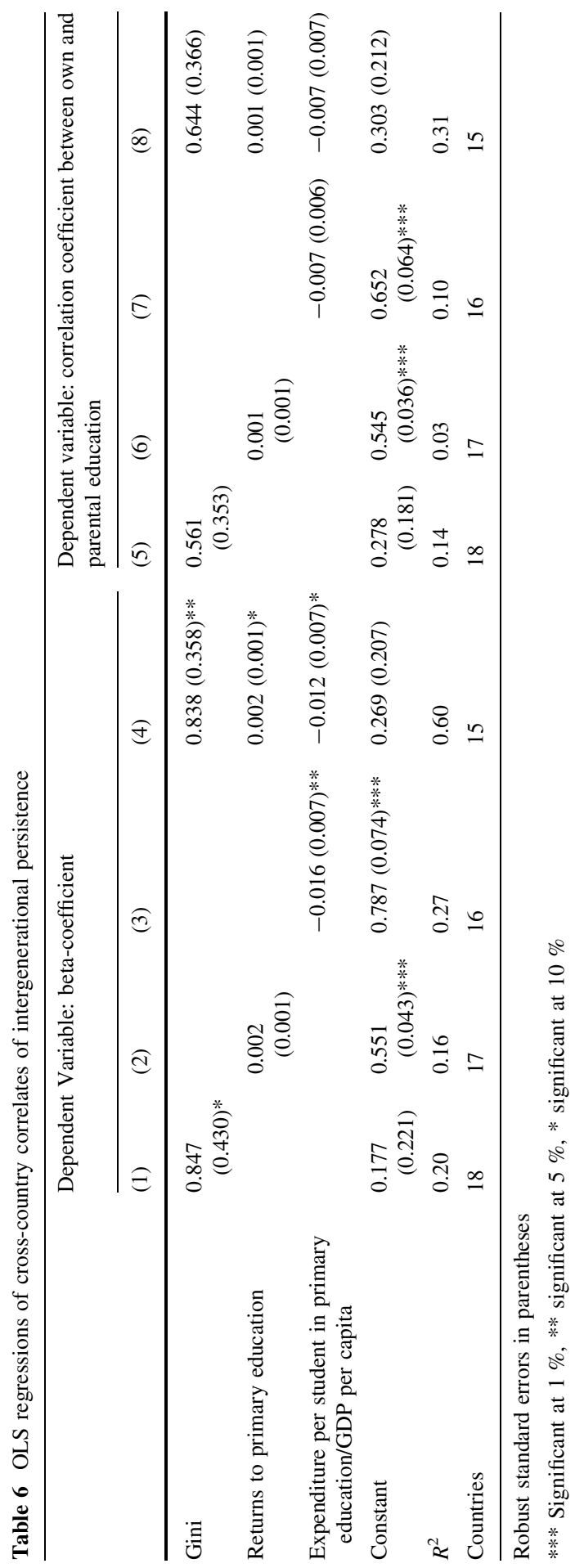




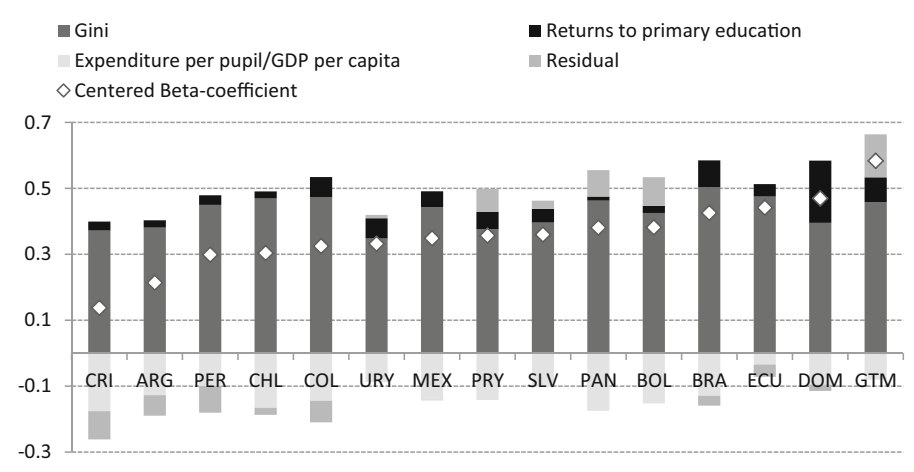

Fig. 9 Contribution to intergenerational persistence of education (beta-coefficient) by country

explaining the country's beta-coefficient. Clearly, although the relative importance varies by country, in all countries income inequality predicts a significant share of the beta-coefficient. The returns to education play a particularly important role in the Dominican Republic, explaining around $38 \%$ of the persistence, while there is a second group of countries where they are important-explaining between 15 and $20 \%$ of the persistence in Uruguay, Brazil, Guatemala and Colombia) and in the rest of the countries returns do not contribute significantly to explaining the level of intergenerational persistence. In terms of the public expenditure on education, the largest contribution to reducing intergenerational persistence in education is for Costa Rica, Panama, and Chile.

Some interesting patterns emerge from this analysis. Costa Rica and Argentina stand out as countries with relatively low intergenerational persistence of education. These are countries where income inequality is historically relatively low and a certain welfare state exists. ${ }^{28}$ Uruguay shares these characteristics, but it differs by having higher returns to education, which might reflect decades of relative low public expenditure in education compared to Costa Rica and Argentina (OECD/ ECLAC 2014). This contrasts with Brazil, Ecuador, Dominican Republic and Guatemala at the other end, which present the highest persistence in educational attainment. In all countries, income inequality plays a major role, although in the case of Dominican Republic the returns to education play an important role, as explained above.

\section{Conclusions and some policy implications}

The present paper has shown that intergenerational mobility in Latin America is low and has not significantly changed for the latest generations, when measured by the importance of parental education in explaining their offspring's educational level. The picture that emerges is that Latin America is not only the most unequal region

\footnotetext{
$\overline{28}$ See Engerman and Sokoloff (1997) and Williamson (2015) for a historical analysis of income inequality and its historical origins in Latin America.
} 
in the world, but also that inequality tends to persist across generations. The index of inequality of opportunity (including dimensions beyond an individual's control such as race, gender and parental income background) is estimated at around $40 \%$, which is high by international standards. The paper also explores country differences in intergenerational mobility. While in Costa Rica, circumstances explain below $15 \%$ of the observed variance in education, in Chile, they amount to almost half the explained variance. The findings imply that there might be room for targeted redistributive policies that improve intergenerational mobility. Next, we discuss some policies that might mitigate these inequalities and reduce the degree of intergenerational persistence.

Recent research points towards the importance of early childhood development (ECD)—comprising cognitive and emotional development as well as adequate health and nutrition - in boosting opportunities for the disadvantaged in developing countries. $^{29}$ Conditional cash-transfer programmes (like Bolsa Família in Brazil, Chile Solidario or PROGRESA/Oportunidades in Mexico), which are often conditional on participation in ECD activities, have shown to be a useful tool for increasing early childhood investments and protecting these investments from adverse shocks. ${ }^{30}$ Evidence from OECD countries shows that higher enrolment rates and increased public spending on pre-school education in early childhood significantly weakens the link between parental education and child secondary education performance. ${ }^{31}$ An expansion of ECD programmes to cover a significant part of the population in Latin America could bring similar benefits. While ECD by itself is not enough to ensure equal opportunities later on, given its complementarity with subsequent investments in skills, it is a precondition-and an area where public policy action could be extremely powerful.

While enrolment rates in primary education in Latin America have generally reached the Millennium Development Goals, secondary schooling is far from being universal in most countries in the region. Making secondary education universal is therefore a natural target for education policy in Latin America. How best to achieve this goal will vary from country to country depending on its circumstances. For example, in several countries, compulsory education covers only 9 years of education ending at age 15). Here, an extension to a 12-year requirement is feasible-e.g. Argentina went from 10 years of compulsory education to 13 in 2007. There are second round benefits to this, as compulsory changes in educational level have transmissible consequences. Evidence from OECD countries-where extensions to mandatory education typically have been at the secondary level-shows that increases in parental education as a result of the expansion of compulsory education have a significant positive effect on the educational outcomes of their offspring. 32

Grants and student loans are also an important tool in boosting access to tertiary education. Evidence for OECD countries shows that the probability of students from

\footnotetext{
29 See Vegas and Santibáñez (2010).

30 de Janvry et al. (2006).

31 Causa and Chapuis (2009).

32 Oreopoulos et al. (2006).
} 
Table 7 Summary statistics by country

\begin{tabular}{|c|c|c|c|c|c|c|c|c|c|c|c|}
\hline Variable & Obs & Mean & $\begin{array}{l}\text { Std. } \\
\text { Dev. }\end{array}$ & Min & Max & Variable & Obs & Mean & $\begin{array}{l}\text { Std. } \\
\text { Dev. }\end{array}$ & Min & Max \\
\hline Argentina & & & & & & Bolivia & & & & & \\
\hline $\begin{array}{l}\text { Own } \\
\text { education }\end{array}$ & 1200 & 10.40 & 3.61 & 0 & 16 & $\begin{array}{l}\text { Own } \\
\text { education }\end{array}$ & 1200 & 8.14 & 5.07 & 0 & 16 \\
\hline $\begin{array}{l}\text { Parental } \\
\text { education }\end{array}$ & 1068 & 7.57 & 4.18 & 0 & 16 & $\begin{array}{l}\text { Parental } \\
\text { education }\end{array}$ & 1027 & 4.83 & 5.17 & 0 & 16 \\
\hline White & 1111 & 0.78 & 0.42 & 0 & 1 & White & 1139 & 0.04 & 0.21 & 0 & 1 \\
\hline Female & 1200 & 0.53 & 0.50 & 0 & 1 & Female & 1200 & 0.50 & 0.50 & 0 & 1 \\
\hline $\begin{array}{l}\text { Parent } \\
\text { income } \\
\text { decile }\end{array}$ & 1045 & 4.95 & 1.85 & 1 & 10 & $\begin{array}{l}\text { Parent } \\
\text { income } \\
\text { decile }\end{array}$ & 1099 & 4.10 & 1.86 & 1 & 10 \\
\hline Brazil & & & & & & Colombia & & & & & \\
\hline $\begin{array}{l}\text { Own } \\
\text { education }\end{array}$ & 1204 & 7.66 & 4.68 & 0 & 16 & $\begin{array}{l}\text { Own } \\
\text { education }\end{array}$ & 1200 & 9.08 & 4.82 & 0 & 16 \\
\hline $\begin{array}{l}\text { Parental } \\
\text { education }\end{array}$ & 1143 & 4.33 & 4.33 & 0 & 16 & $\begin{array}{l}\text { Parental } \\
\text { education }\end{array}$ & 1158 & 5.12 & 4.56 & 0 & 16 \\
\hline White & 1193 & 0.48 & 0.50 & 0 & 1 & White & 1047 & 0.29 & 0.45 & 0 & 1 \\
\hline Female & 1204 & 0.52 & 0.50 & 0 & 1 & Female & 1200 & 0.63 & 0.48 & 0 & 1 \\
\hline $\begin{array}{l}\text { Parent } \\
\text { income } \\
\text { decile }\end{array}$ & 1128 & 4.64 & 1.97 & 1 & 10 & $\begin{array}{l}\text { Parent } \\
\text { income } \\
\text { decile }\end{array}$ & 962 & 4.03 & 2.24 & 1 & 10 \\
\hline Costa Rica & & & & & & Chile & & & & & \\
\hline $\begin{array}{l}\text { Own } \\
\text { education }\end{array}$ & 1000 & 7.84 & 4.39 & 0 & 16 & $\begin{array}{l}\text { Own } \\
\text { education }\end{array}$ & 1200 & 10.64 & 3.92 & 0 & 16 \\
\hline $\begin{array}{l}\text { Parental } \\
\text { education }\end{array}$ & 826 & 4.77 & 4.10 & 0 & 16 & $\begin{array}{l}\text { Parental } \\
\text { education }\end{array}$ & 1040 & 8.40 & 4.54 & 0 & 16 \\
\hline White & 916 & 0.47 & 0.50 & 0 & 1 & White & 1133 & 0.72 & 0.45 & 0 & 1 \\
\hline Female & 1000 & 0.50 & 0.50 & 0 & 1 & Female & 1200 & 0.53 & 0.50 & 0 & 1 \\
\hline $\begin{array}{l}\text { Parent } \\
\text { income } \\
\text { decile }\end{array}$ & 833 & 5.44 & 1.91 & 1 & 10 & $\begin{array}{l}\text { Parent } \\
\text { income } \\
\text { decile }\end{array}$ & 1117 & 4.41 & 1.61 & 1 & 10 \\
\hline \multicolumn{6}{|c|}{ Dominican Republic } & Ecuador & & & & & \\
\hline $\begin{array}{l}\text { Own } \\
\text { education }\end{array}$ & 1000 & 8.22 & 4.77 & 0 & 16 & $\begin{array}{l}\text { Own } \\
\text { education }\end{array}$ & 1200 & 8.05 & 4.75 & 0 & 16 \\
\hline $\begin{array}{l}\text { Parental } \\
\text { education }\end{array}$ & 687 & 5.46 & 4.92 & 0 & 16 & $\begin{array}{l}\text { Parental } \\
\text { education }\end{array}$ & 1182 & 5.44 & 4.65 & 0 & 16 \\
\hline White & 988 & 0.15 & 0.36 & 0 & 1 & White & 1119 & 0.09 & 0.29 & 0 & 1 \\
\hline Female & 1000 & 0.50 & 0.50 & 0 & 1 & Female & 1200 & 0.50 & 0.50 & 0 & 1 \\
\hline $\begin{array}{l}\text { Parent } \\
\text { income } \\
\text { decile }\end{array}$ & 914 & 4.06 & 1.71 & 1 & 10 & $\begin{array}{l}\text { Parent } \\
\text { income } \\
\text { decile }\end{array}$ & 1123 & 4.20 & 1.95 & 1 & 10 \\
\hline El Salvador & & & & & & Guatemala & & & & & \\
\hline $\begin{array}{l}\text { Own } \\
\text { education }\end{array}$ & 1000 & 6.70 & 5.00 & 0 & 16 & $\begin{array}{l}\text { Own } \\
\text { education }\end{array}$ & 1000 & 4.51 & 4.56 & 0 & 16 \\
\hline $\begin{array}{l}\text { Parental } \\
\text { education }\end{array}$ & 963 & 2.60 & 4.25 & 0 & 16 & $\begin{array}{l}\text { Parental } \\
\text { education }\end{array}$ & 834 & 2.49 & 3.96 & 0 & 16 \\
\hline
\end{tabular}


Table 7 continued

\begin{tabular}{|c|c|c|c|c|c|c|c|c|c|c|c|}
\hline Variable & Obs & Mean & $\begin{array}{l}\text { Std. } \\
\text { Dev. }\end{array}$ & Min & Max & Variable & Obs & Mean & $\begin{array}{l}\text { Std. } \\
\text { Dev. }\end{array}$ & Min & Max \\
\hline White & 926 & 0.11 & 0.32 & 0 & 1 & White & 923 & 0.15 & 0.35 & 0 & 1 \\
\hline Female & 1000 & 0.53 & 0.50 & 0 & 1 & Female & 1000 & 0.50 & 0.50 & 0 & 1 \\
\hline $\begin{array}{l}\text { Parent } \\
\text { income } \\
\text { decile }\end{array}$ & 765 & 4.33 & 2.31 & 1 & 10 & $\begin{array}{l}\text { Parent } \\
\text { income } \\
\text { decile }\end{array}$ & 801 & 3.58 & 2.07 & 1 & 10 \\
\hline Honduras & & & & & & Mexico & & & & & \\
\hline $\begin{array}{l}\text { Own } \\
\text { education }\end{array}$ & 1000 & 6.04 & 4.08 & 0 & 16 & $\begin{array}{l}\text { Own } \\
\text { education }\end{array}$ & 1200 & 8.61 & 4.82 & 0 & 16 \\
\hline $\begin{array}{l}\text { Parental } \\
\text { education }\end{array}$ & 910 & 2.76 & 3.78 & 0 & 16 & $\begin{array}{l}\text { Parental } \\
\text { education }\end{array}$ & 1193 & 5.03 & 5.05 & 0 & 16 \\
\hline White & 949 & 0.19 & 0.39 & 0 & 1 & White & 887 & 0.12 & 0.33 & 0 & 1 \\
\hline Female & 1000 & 0.50 & 0.50 & 0 & 1 & Female & 1200 & 0.52 & 0.50 & 0 & 1 \\
\hline $\begin{array}{l}\text { Parent } \\
\text { income } \\
\text { decile }\end{array}$ & 843 & 4.06 & 2.29 & 1 & 10 & $\begin{array}{l}\text { Parent } \\
\text { income } \\
\text { decile }\end{array}$ & 1018 & 4.59 & 2.15 & 1 & 10 \\
\hline Nicaragua & & & & & & Panama & & & & & \\
\hline $\begin{array}{l}\text { Own } \\
\text { education }\end{array}$ & 1000 & 5.53 & 4.72 & 0 & 16 & $\begin{array}{l}\text { Own } \\
\text { education }\end{array}$ & 1000 & 8.05 & 4.78 & 0 & 16 \\
\hline $\begin{array}{l}\text { Parental } \\
\text { education }\end{array}$ & 907 & 3.61 & 4.56 & 0 & 16 & $\begin{array}{l}\text { Parental } \\
\text { education }\end{array}$ & 820 & 4.45 & 4.98 & 0 & 16 \\
\hline White & 915 & 0.09 & 0.28 & 0 & 1 & White & 984 & 0.18 & 0.39 & 0 & 1 \\
\hline Female & 1000 & 0.51 & 0.50 & 0 & 1 & Female & 1000 & 0.50 & 0.50 & 0 & 1 \\
\hline $\begin{array}{l}\text { Parent } \\
\text { income } \\
\text { decile }\end{array}$ & 865 & 3.36 & 2.31 & 1 & 10 & $\begin{array}{l}\text { Parent } \\
\text { income } \\
\text { decile }\end{array}$ & 804 & 4.43 & 2.15 & 1 & 10 \\
\hline Paraguay & & & & & & Peru & & & & & \\
\hline $\begin{array}{l}\text { Own } \\
\text { education }\end{array}$ & 1200 & 8.89 & 4.21 & 0 & 16 & $\begin{array}{l}\text { Own } \\
\text { education }\end{array}$ & 1200 & 9.07 & 4.79 & 0 & 16 \\
\hline $\begin{array}{l}\text { Parental } \\
\text { education }\end{array}$ & 995 & 6.19 & 4.24 & 0 & 16 & $\begin{array}{l}\text { Parental } \\
\text { education }\end{array}$ & 1162 & 6.28 & 5.30 & 0 & 16 \\
\hline White & 838 & 0.47 & 0.50 & 0 & 1 & White & 1082 & 0.07 & 0.25 & 0 & 1 \\
\hline Female & 1200 & 0.50 & 0.50 & 0 & 1 & Female & 1200 & 0.50 & 0.50 & 0 & 1 \\
\hline $\begin{array}{l}\text { Parent } \\
\text { income } \\
\text { decile }\end{array}$ & 1122 & 4.47 & 1.94 & 1 & 10 & $\begin{array}{l}\text { Parent } \\
\text { income } \\
\text { decile }\end{array}$ & 1093 & 3.83 & 2.04 & 1 & 10 \\
\hline Uruguay & & & & & & Venezuela & & & & & \\
\hline $\begin{array}{l}\text { Own } \\
\text { education }\end{array}$ & 1200 & 8.74 & 3.73 & 0 & 16 & $\begin{array}{l}\text { Own } \\
\text { education }\end{array}$ & 1200 & 10.62 & 4.04 & 0 & 16 \\
\hline $\begin{array}{l}\text { Parental } \\
\text { education }\end{array}$ & 1010 & 6.77 & 3.74 & 0 & 16 & $\begin{array}{l}\text { Parental } \\
\text { education }\end{array}$ & 1161 & 7.36 & 4.73 & 0 & 16 \\
\hline White & 1164 & 0.87 & 0.34 & 0 & 1 & White & 1094 & 0.34 & 0.47 & 0 & 1 \\
\hline Female & 1200 & 0.53 & 0.50 & 0 & 1 & Female & 1200 & 0.50 & 0.50 & 0 & 1 \\
\hline
\end{tabular}


Table 7 continued

\begin{tabular}{lccccccccccc}
\hline Variable & Obs & Mean & $\begin{array}{l}\text { Std. } \\
\text { Dev. }\end{array}$ & Min & Max & Variable & Obs & Mean & $\begin{array}{l}\text { Std. } \\
\text { Dev. }\end{array}$ & Min & Max \\
\hline $\begin{array}{l}\text { Parent } \\
\begin{array}{l}\text { income } \\
\text { decile }\end{array}\end{array}$ & 1023 & 5.07 & 2.08 & 1 & 10 & $\begin{array}{c}\text { Parent } \\
\text { income } \\
\text { decile }\end{array}$ & 1057 & 5.00 & 1.75 & 1 & 10 \\
\hline
\end{tabular}

White is a binary variable indicating self-reported racial origin-question s11; Female is a binary variable indicating whether individual is female; PID stands for parent income 10-quantile classification-question p12stb

less favourable family backgrounds completing tertiary studies is higher in countries that provide funding available to all students.

Finally, many other social policies might be complementary to the ones previously mentioned. Better access to unemployment insurance, health services and social protection would allow families to withstand the kind of liquidity shocks that currently often require teenagers to postpone or abandon their studies to provide supplementary income for the household. It is important to consider the institutional capacities of each country and to conduct a careful evaluation of what policy might be best in each case.

Open Access This article is distributed under the terms of the Creative Commons Attribution 4.0 International License (http://creativecommons.org/licenses/by/4.0/), which permits unrestricted use, distribution, and reproduction in any medium, provided you give appropriate credit to the original author(s) and the source, provide a link to the Creative Commons license, and indicate if changes were made.

\section{Appendix}

This appendix presents a brief sketch of a model by Solon (2004) that is useful to analyse the intergenerational transmission of income and to assess the central role of education.

We assume that the parental budget constraint of household $i$ is given by:

$$
(1-\eta) y_{i t-1}=C_{i t-1}+I_{i t-1},
$$

where the left-hand represents disposable income and $\eta$ is the tax rate, $C$ is parental consumption and $I$ is investment in the offspring's education. The parent's utility function is given by:

$$
U_{i t-1}=(1-\alpha) \log C_{i t-1}+\alpha \log y_{i t},
$$

such that parent care about the own consumption and their offspring's income level. Educational attainment is composed by two parts: a deliberate accumulation process [either through public $(G)$ or private $(I)$ investment in education] and an inheritable fraction $(e)$. 


$$
h_{i t}=\theta\left(I_{i t-1}+G_{i t-1}\right)+e_{i t},
$$

The inheritable endowments follow a stationary autoregressive process of order one given by:

$$
e_{i t}=\delta+\lambda e_{i t-1}+v_{i t},
$$

where the last term is a white noise random shock. These endowments should be interpreted in a broad sense. They include innate ability, but also other attributes that are determined by the family's network, race, or culture. Educational attainment increases income via a standard Mincer equation, given by:

$$
\log y_{i t}=\mu+p h_{i t} .
$$

Following Solon (2004), public policy can be represented by:

$$
\frac{G_{i t-1}}{(1-\tau) y_{i t-1}} \cong \phi-\gamma \log y_{i t-1},
$$

where $\gamma>0$. According to this equation, public investment in children's educational attainment is progressive in relative terms, as public investment as a fraction of parental disposable income decreases with the level of income. Utility maximisation and operating yields the following steady-state relationship between parental and own education:

$$
\begin{aligned}
h_{i t} & \cong \theta\left[(1-\gamma) \mu+\phi+\log \left(\frac{\alpha \theta p(1-\tau)}{1-\alpha(1-\theta p)}\right)\right]+\theta p(1-\gamma) h_{i t-1}+e_{i t} \\
& =\mu^{*}+\psi h_{i t-1}+e .
\end{aligned}
$$

An OLS estimation of Eq. (13) would be biased and inconsistent, as the error term is correlated with the parent's education. However, it is straightforward to show that the correct steady-state measure of intergenerational transmission of educational attainments $(\psi)$ is given by:

$$
\psi=\frac{\theta p(1-\gamma)+\lambda}{1+\theta p(1-\gamma) \lambda} .
$$

Thus, in theory, the degree of intergeneration transmission is an increasing function of the productivity of educational attainments $(\theta)$, the returns to education $(p)$ and the persistence in intergenerational inheritance of skills and other relevant characteristics $(\lambda)$, while more progressivity of public investment in education $(\gamma)$ increases intergenerational educational mobility. Differences across countries should therefore be related to differences in these parameters.

Furthermore, using Eqs. (11) and (13), the variance in steady-state (log) income is given by: 


$$
\operatorname{var}(\log y)=\frac{(1+(1-\gamma) \theta p \lambda) p^{2}}{(1-(1-\gamma) \theta p \lambda)\left(1-\lambda^{2}\right)\left[1-(1-(1-\gamma) \theta p)^{2}\right]} \sigma_{v}^{2}
$$

where is the variance of the innovation term in Eq. (10). Therefore, in steady state, the dispersion in income increases with the degree of inheritability $(\lambda)$, the productivity of educational investments $(\theta)$, and the returns to education $(p)$, and decreases with the progressivity of public policies $(\gamma)$, just like the intergeneration elasticity (see Eq. 14).

However, there is no one-to-one mapping between intergenerational mobility and inequality, as the latter depends also on the dispersion of income-related characteristics that are not included in the beta-coefficient measure used in our analysis.

\section{References}

Aiyagari SR, Greenwood J, Seshadri A (2003) Efficient investment in children. J Econ Theory 102:290-321

Andersen LE (2001) Social mobility in Latin America: links to adolescent schooling. Research Network Working Paper R-433, Research Department, Inter-American Development Bank, Washington, DC

Angrist J, Pischke JS (2009) Mostly harmless econometrics: an empiricist's companion. Princeton University Press, Princeton

Azevedo VMR, Bouillon CP (2010) Intergenerational social mobility in Latin America: a review of existing evidence. Revista de Análisis Económico 25(2):7-42

Becker GS, Tomes N (1979) An equilibrium theory of the distribution of income and intergenerational mobility. J Polit Econ 87(6):1153-1189

Becker GS, Tomes N (1986) Human capital and the rise and fall of families. J Labor Econ 4(3):1-39

Behrmann J, Birdsall N, Székely M (1999) Intergenerational mobility in Latin America: deeper markets and better schools make a difference. In: Birdsall N, Graham C (eds) New markets, new opportunities? Economic and social mobility in a changing world. Brookings Institution, Washington DC

Behrmann J, Gaviria A, Székely M (2001) Intergenerational mobility in Latin America. Economía 2(1): $1-44$

Björklund A, Jäntti M, Solon G (2007) Nature and nurture in the intergenerational transmission of socioeconomic status: evidence from Swedish children and their biological and rearing parents. BE J Econ Anal Policy 7(2):1-23

Black SE, Devereux PJ (2010) Recent developments in intergenerational mobility./ NBER Working Paper No. 15889, Cambridge MA

Brunori P, Ferreira FHG, Peragine V (2013). Inequality of opportunity, income inequality and economic mobility: some international comparisons. The World Bank Development Research Group WP 6304, January

Carrillo P, Gandelman N, Robano V (2014) Glass ceilings and sticky floors in Latin America: an analysis of the gender wage gap. J Econ Inequal 12(3):339-361

Causa O, Chapuis C (2009) Equity in student achievement across OECD countries: an investigation of the role of policies. OECD Economics Department Working Papers, No. 708, OECD, Paris

Causa O, Dantan S, Johansson $\AA$ (2009) Intergenerational social mobility in European OECD countries. OECD Economics Department Working Papers, No. 709

Conconi A, Cruces G, Olivieri S, Sánchez R (2007) E pur si muove? Movilidad, Pobreza y Desigualdad en América Latina. Working Paper, No. 62, CEDLAS

Corak M (2013) Income inequality, equality of opportunity, and intergenerational mobility. J Econ Perspect 27(3):79-102 
Cuesta J, Nopo H, Pizzolitto G (2011) Using Pseudo-panels to measure income mobility in Latin America. Review of Income and Wealth, Series 57(2), June

Daude C (2011) Ascendance by descendants? On intergenerational education mobility in Latin America. OECD Development Centre Working Papers No. 297

de Janvry A, Finan F, Sadoulet E, Vakis R (2006) Can Conditionnal Cash Transfers Serve as Safety Nets in Keeping Children at School and from Working when Exposed to Shocks? J Dev Econ 79(2):349-373

Engerman SL, Sokoloff KL (1997) Factor endowments, institutions, and differential paths of growth among new world economies. In: Haber S (ed) How Latin America fell behind. Stanford University Press, Palo Alto, pp 260-304

Ferreira FHG, Gignoux J (2011) The measurement of inequality of opportunity: theory and an application to Latin America. Review of Income and Wealth, series 57, No. 4, December 2011, pp 622-657

Ferreira FHG, Gignoux J (2013) The measurement of educational inequality: achievement and opportunity. World Bank Econ Rev 28(2):210-246

Gandelman N, Robano V (2014) Intergenerational mobility and entrepreneurship in Uruguay. Lat Am J Econ 51(2):195-226

Hertz T, Jayasundera T, Piraino P, Selcuk S, Smith N, Verashchagina A (2007) Intergenerational economic mobility around the world. BE J Econ Anal Policy 7(2):1-45

Ñopo H, Chong A, Moro A (2010) Discrimination in Latin America: an economic perspective. InterAmerican Development Bank, Palgrave

OECD (2008) Latin American economic outlook 2009. OECD Development Centre, Paris

OECD (2010) A family affair: intergenerational social mobility across OECD countries. Economic policy reforms going for growth 2010. OECD Publishing, Paris, pp 181-198

OECD/ECLAC (2014) Multi-dimensional Review of Uruguay, vol 1., Initial assessment, OECD Development pathwaysOECD Publishing, Paris

Oreopoulos P, Marianne EP, Stevens AH (2006) The intergenerational effects of compulsory schooling. J Labor Econ 24(4):729-760

Psacharopoulos G, Patrinos HA (2004) Returns to investment in education: a further update. Educ Econ 12(2):111-134

Roemer JE (1998) Equality of opportunity. Harvard University Press, Cambridge

Solon G (2002) Cross-country differences in intergenerational earnings mobility. J Econ Perspect 16(3):59-66

Solon G (2004) A model of intergenerational mobility variation over time and place. In: Corak M (ed) Generational income mobility in North America and Europe

Tejerina L, Westley G (2007) Financial services for the poor: household survey sources and gaps in borrowing and saving. Technical Papers Series POV-117, Sustainable Development Department, Inter-American Development Bank

Torche F (2014) Intergenerational mobility and inequality: the Latin American case. Annu Rev Sociol 40:619-642

Vegas E, Santibáñez L (2010) The Promise of Early Childhood Development in Latin America and the Caribbean. The World Bank, Washington DC

Williamson JG (2015) Latin American inequality: colonial origins, commodity booms, or a missed 20th century leveling? NBER Working Paper \#20915, January, Cambridge, MA 